OPEN ACCESS

Edited by:

Maria Grazia Pennino, Spanish Institute of Oceanography,

Spain

Reviewed by:

Sven Alexander Kranz,

Florida State University, United States

Corday Selden,

Old Dominion University,

United States

*Correspondence:

Mar Benavides

mar.benavides@ird.fr

${ }^{\dagger}$ These authors have contributed equally to this work

Specialty section: This article was submitted to

Marine Conservation and Sustainability,

a section of the journa

Frontiers in Marine Science

Received: 02 June 2020 Accepted: 03 September 2020 Published: 29 September 2020

Citation:

Benavides $M$ and Robidart $J$ (2020) Bridging the Spatiotemporal

Gap in Diazotroph Activity and Diversity With High-Resolution

Measurements.

Front. Mar. Sci. 7:568876 doi: 10.3389/fmars.2020.568876

\section{Bridging the Spatiotemporal Gap in Diazotroph Activity and Diversity With High-Resolution Measurements}

\author{
Mar Benavides ${ }^{1 * \dagger}$ and Julie Robidart ${ }^{2 \dagger}$ \\ ${ }^{1}$ Aix Marseille Univ, Université de Toulon, CNRS, IRD, MIO UM 110, Marseille, France, ${ }^{2}$ Ocean Technology and Engineering \\ Group, National Oceanography Centre, Southampton, United Kingdom
}

The biological fixation of dinitrogen $\left(\mathrm{N}_{2}\right)$ by marine microbes called "diazotrophs" sustains $\sim 50 \%$ new production in the ocean, boosting $\mathrm{CO}_{2}$ absorption by photoautotrophs and thus contributing to the mitigation of climate change. New environmental conditions sustaining $\mathrm{N}_{2}$ fixation have been revealed in recent years, enabling more accurate forecasting of future nitrogen inputs and localized hot spots. However, at present the paucity and biased geographical coverage of $\mathrm{N}_{2}$ fixation and diazotroph diversity measurements impede attempts to reconcile global nitrogen budgets with observed rates. Most studies have been conducted at disparate spatiotemporal scales, including: (i) discrete and short duration measurements in small seawater volumes isolated from the environment, and (ii) spatial extrapolations and global models of diazotrophy projected over decades to centuries. We argue that this knowledge gap lies at the fine scales: dynamic seawater structures $<200 \mathrm{~km}$ wide and $<2$ months lifetime. However, the spatiotemporal resolution of conventional oceanographic cruises, with stations separated by tens to hundreds of kilometers, is too poor to resolve fine scale processes. Bridging this gap requires leveraging high spatiotemporal resolution measurements. Here we present and discuss the advantages and disadvantages of contemporary methods and equipment able to provide highresolution measurements at sea. We also provide insights into high-resolution sampling approaches to be developed in the near future. Increasing the spatiotemporal resolution of diazotroph activity and diversity will provide more realistic quantifications of nitrogen fluxes in the dynamic ocean.

Keywords: diazotrophs, fine scale dynamics, physical-biological coupling, cyanobacteria, $\mathbf{N}_{2}$ fixation

\section{THE GAP IN OCEANIC N 2 FIXATION}

Nitrogen is considered the predominant nutrient limiting primary production in the ocean (Tyrrell, 1999). Most of the ocean surface is too remote to benefit from land and atmospheric inputs but can receive from dinitrogen $\left(\mathrm{N}_{2}\right)$ fixation: the reduction of $\mathrm{N}_{2}$ to ammonia carried out by specialized types of microbes called "diazotrophs." Diazotrophs play a crucial role in ocean biogeochemistry: they sustain $\sim 50 \%$ of marine new production (Mahaffey et al., 2005) and can contribute $>70 \%$ to carbon sequestration in the vast oligotrophic regions of the ocean (Karl et al., 2012; Caffin et al., 2018). 
Our current knowledge of diazotroph diversity and activity (diazotrophy) is derived from disparate spatiotemporal scales (Figure 1). At smaller spatiotemporal scales, diazotrophs are studied by manipulating communities in incubation bottles with restricted volumes (typically $<5 \mathrm{~L}$ ). Such incubations require a physical isolation from their environment, which can lead to exposure to well known "bottle effects" that introduce bias in our results (Zobell and Anderson, 1936). These small scale discrete incubations as well as local nutrient climatologies can be used to extrapolate rates of $\mathrm{N}_{2}$ fixation regionally (e.g., Hansell et al., 2004; Luo et al., 2012). On larger scales, the isotopic composition of dissolved and particulate nitrogen are used to infer regional $\mathrm{N}_{2}$ fixation rates (e.g., Bates and Hansell, 2004; Knapp et al., 2016). Mathematical models allow the extrapolation of diazotroph and $\mathrm{N}_{2}$ fixation rate distribution patterns up to the global scale (Ward et al., 2013; Dutkiewicz et al., 2014; Gruber, 2016). Current estimates of fixed nitrogen inputs to the ocean via small or large scale approaches vary by dozens of $\mathrm{Tg} \mathrm{N}$ $\mathrm{y}^{-1}$ (Luo et al., 2012; Landolfi et al., 2018). These discrepancies are perhaps not surprising given the spatiotemporal variation between these approaches.

Flow instabilities such as mesoscale (10-200 km, weeks) and submesoscale (1-10 km, days) structures-here collectively referred to as "fine scales" - control major processes fundamental to microbial physiology, including nutrient advection and export (Falkowski et al., 1991; Johnson et al., 2010; Guidi et al., 2012). Despite their importance, there is currently a spatiotemporal gap between small- and large-scale approaches in typical oceanographic research, limiting our understanding of microbial dynamics at fine scales (Figure 1). The inherent dynamic and sporadic character of fine scale structures makes them difficult to observe on individual oceanographic cruises (Mahadevan, 2016; McGillicuddy, 2016). Satellite ocean color data enables the observation of how fine scale dynamics accumulate or disperse chlorophyll, and even specific groups of phytoplankton (reviewed in Lehahn et al., 2017a). These approaches have formed a solid foundational understanding of physical-biological interactions in the ocean. However, in situ sampling remains imperative to measure changes in distributions at depth and microbial processes, which cannot be captured by satellite oceanography. Typical oceanographic cruises transect geographic locations separated by hundreds to a few thousand kilometers. With a regular navigation speed of $\sim 18 \mathrm{~km} \mathrm{~h}^{-1}$ (or $10 \mathrm{kn}$ ) and sampling operations that last several hours, such approaches result in poor spatiotemporal resolution sampling, incapable of resolving fine scale dynamics for most chemical and biological processes (Lévy et al., 2012).

As the physical features that create biogeochemical conditions dictating microbial activity, fine scale structures should be a focus, but they require a sampling scale that matches the structure of interest (Lévy et al., 2012). Recent technological advances have significantly improved this resolution. In this perspective, we provide an overview of the role of fine scale processes in structuring diazotrophic communities, the available tools to measure diazotrophic activity, abundance and diversity at high spatiotemporal resolution, and provide recommendations for future developments in the field.

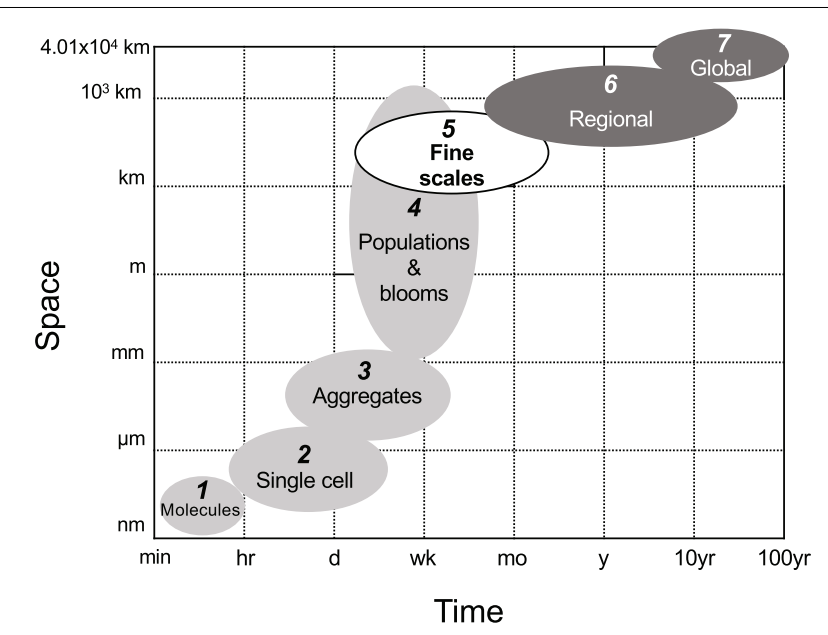

FIGURE 1 | The spatiotemporal scales of diazotrophy studies in the ocean ranging from minutes to 100 years in time and from $\mathrm{nm}$ to $4.01 \times 10^{4} \mathrm{~km}$ (the circumference of the Earth) in space. Light and dark gray ellipsoids depict the spatiotemporal scales of diazotrophy studied to date, i.e., lower and larger scales in light and dark gray, respectively. The white ellipsoid depicts the current gap in knowledge: the fine scales. This gap can only be filled by developing novel methods capable of measuring diazotroph community composition, abundance and activity at high spatiotemporal resolution. (1) We refer as "molecules" to molecular processes covered in transcriptomic studies. Gene transcription typically takes place in a time range of minutes. (2) The interaction between molecules and cells is approached by nano- to microscale techniques exploring chemical microenvironments with microsensors (e.g., Eichner et al., 2017, 2019), substrate uptake using nanoscale secondary ion mass spectrometry (e.g., Finzi-Hart et al., 2009; Thompson et al., 2012; Bonnet et al., 2016), or molecular marking targeting proteins (e.g., Lin et al., 1998; Foster et al., 2006; Hynes et al., 2009) at the single-cell level. This spatiotemporal scale ranges in space from the size of intracellular compartments visible with those techniques to the maximum size of a single diazotroph cell. In time, this spatiotemporal scale reaches the maximum incubation time used in such studies, i.e., usually up to $72 \mathrm{~h}$. (3) The localization of substrates or sub-cellular structures of interest in colonies and or aggregates can be approached with the techniques included in (2). The size, shape and horizontal/vertical distribution of aggregates in the ocean is usually resolved with microscopy (e.g., White et al., 2018), bench flow cytometry (Bombar et al., 2013; Mclnnes et al., 2014), field semiautomated flow cytometry (Dugenne et al., 2020), or automated underway devices such as the video plankton recorder (Davis and McGillicuddy, 2006). The size of this spatiotemporal scale ranges from tens of microns to several $\mathrm{mm}$. The time range is considered to range between several hours and a few weeks, although the fate of aggregates in the ocean or how long they remain intact or alive is uncertain. (4) The composition and distribution of diazotroph populations is usually approached by discrete sampling along oceanographic cruise transects spanning hundreds to a few thousands of km. Such studies cover a time range from a few days to several weeks and depict communities using microscopy and/or molecular analyses such as quantitative PCR (e.g., Moisander et al., 2010; Bonnet et al., 2015; Benavides et al., 2016; Shiozaki et al., 2017). Trichodesmium blooms can cover extensions of hundreds to thousands of square $\mathrm{km}$ and are studied with customized algorithms applied to satellite products such as SeaWiFS or MODIS (Hood et al., 2002;

Subramaniam et al., 2002; Rousset et al., 2018). (5) Submesoscale (1-10 km, days) structures such as filaments, and mesoscale (10-200 km, several weeks) structures including fronts and eddies (here collectively referred to as "fine scales," see section "How Fine Scale Processes May Affect Diazotrophs" of the main text). Studies seeking to link fine scales to diazotrophy have conducted discrete sampling along the central edge of mesoscale eddies at stations situated tens of km apart at best (e.g., Fong et al., 2008; Zhang et al., 2011; Löscher et al., 2016; Liu et al., 2020). In these studies, the distribution

(Continued) 


\section{FIGURE 1 | Continued}

and activity of diazotrophs has been approached with traditional methods for the characterization of the diazotroph community (i.e., microscopy, quantitative $\mathrm{PCR},{ }^{15} \mathrm{~N}_{2}$ stable isotope incubations). Underway $\mathrm{N}_{2}$ fixation rate measurements hold great promise in providing submesoscale resolved data (e.g., Moore et al., 2018; Tang et al., 2019), but to date such approaches have not been investigated in depth with parallel physical oceanography parameters. (6) Regional studies often stem from direct $\mathrm{N}_{2}$ fixation rates or diazotroph abundance measurements obtained from a single oceanographic cruise or a combination of several datasets extrapolated over a given region (Luo et al., 2012; Tang et al., 2019). Indirect methods to obtain $\mathrm{N}_{2}$ fixation estimates such as the $\mathrm{N}^{*}$ parameter or $\delta^{15} \mathrm{~N}$ distributions (e.g., Hansell et al. 2004; Deutsch et al., 2007) as well as modeling approaches integrating nutrient climatologies, repeated transect datasets and ocean circulation (Landolfi et al., 2008; Torres-Valdés et al., 2009) have also been used to infer regional diazotrophy estimates. The temporal span of this scale is thus large, ranging from several weeks to tens of years. Finally, (7) global marine diazotrophy studies have been addressed with models integrating biogeochemistry, ecological and circulation models (e.g., Monteiro et al., 2011; Dutkiewicz et al., 2014; Wang et al., 2019). At present, our poor mechanistic knowledge of the diversity, physiology, trophic interactions and environmental constrains of different diazotrophs, combined with computational power constraints makes it difficult to run models considering more than two or three diazotroph ecotypes. The numbering of the different spatiotemporal scales considered in this figure is illustrative and does not intend to exclude possible subdivisions, overlaps or clustering between scales in marine diazotrophy yet to be described by new techniques and sampling approaches.

\section{HOW FINE SCALE PROCESSES MAY AFFECT DIAZOTROPHS}

Although there are a limited number of diazotroph taxa, their ecologies are very distinct (referred to here as "ecotypes"; Thompson and Zehr, 2013), with different morphologies, activities and physiological constraints which dictate their biogeographical and seasonal distribution globally (Zehr and Capone, 2020). Due to the high variability of physical and chemical factors at the fine scale, the extent to which physical features affect diazotrophs will depend on how the resulting physicochemical changes affect each ecotype's physiology and metabolism (Lévy et al., 2012). Due to the range of factors contributing to the relative success of each ecotype, rates alone cannot provide enough information to model diazotrophy. It is necessary to collect rates while quantifying the organism(s) responsible to better characterize the bottom-up controls on distributions and activities of each ecotype.

Fine scales comprise a wide range of structures including filaments, fronts and eddies, with different physical dynamics that influence their biogeochemical properties. For example, vertical transport in submesoscale fronts causes rapid injections of deep nutrient rich waters, enhancing phytoplankton growth locally (Mahadevan, 2016). It is uncertain to which extent diazotrophs may benefit from such rapid inputs given their slow growth rates. Horizontal stirring strains fine scale features into thinner filaments, distributing phytoplankton niches (d'Ovidio et al., 2010) and regulating the access to limiting nutrients and mortality due to grazing and viral infection (Lehahn et al., 2017b). The success of a given species will depend on the balance between physical and biological time scales, e.g., when nutrient delivery promotes sufficient growth to overcome grazing and viral pressure (Lehahn et al., 2017b).

Eddy trapping can isolate planktonic assemblages in Lagrangian coherent structures where lateral exchange with surrounding waters is limited (Lehahn et al., 2011). Such structures may act as a shield impeding dilution of nutrients permitting phytoplankton growth, or as a trap if a given species gets "trapped with the enemy" (i.e., predator; Bracco et al., 2000; Lehahn et al., 2014). Mills and Arrigo (2010) argued that nonRedfield usage of nutrients by non-diazotrophic phytoplankton lowers $\mathrm{N}: \mathrm{P}$ ratios, creating diazotroph niches. Following this logic, we hypothesize that non-diazotrophic phytoplankton thrive in coherent eddies until the nitrogen trapped within them is depleted. While non-diazotrophic phytoplankton thrive, diazotrophs would be outcompeted (likely with the exception of UCYN-A, as discussed below). Once nitrogen is depleted diazotrophs may succeed, benefiting from a decrease in competition for phosphorus and trace metals with nondiazotrophic phytoplankton. This balance is likely further set by grazing and viral infection on diazotrophs. Indeed, Dugenne et al. (2020) observed higher growth rates and lowered grazing pressure on Crocosphaera inside a lower-biomass anticyclonic eddy as compared to a cyclonic eddy.

Eddy pumping is postulated to explain differences in diazotroph abundance and/or $\mathrm{N}_{2}$ fixation rates, i.e., anticyclonic eddies deepen isopycnals, lowering nutrient availability and promoting diazotroph development, while the reverse occurs in cyclonic eddies. For example, Trichodesmium is sensitive to dissolved inorganic nitrogen (Knapp et al., 2012) and accumulates in anticyclonic eddies (Davis and McGillicuddy, 2006; Fong et al., 2008). However, anticyclones do not only hamper the upwelling of nitrate, but also of dissolved inorganic and organic phosphorus which exert an important control in the growth and diazotrophic activity of Trichodesmium (e.g., Dyhrman et al., 2006; Hynes et al., 2009).

Trichodesmium harbors gas vesicles that provide them with buoyancy control (Villareal and Carpenter, 2003). Trichodesmium may be thus treated as buoyant particles accumulating at frontal structures (Taylor, 2018). Forced accumulation at surface frontal structures may increase nutrient limitation in Trichodesmium colonies while increasing sunlight exposure, potentially inducing cell mortality via autocatalytic death pathways and thereby vertical export (Berman-Frank et al., 2004). The unicellular diazotroph Crocosphaera watsonii can be found as small $(2-3.5 \mu \mathrm{m})$ and large $(4-5 \mu \mathrm{m})$ cell types (Bench et al., 2016). While the oligotrophic conditions that promote Trichodesmium in anticyclonic eddies similarly contribute to the proliferation of C. watsonii (Fong et al., 2008; Liu et al., 2020), physical accumulation at high density frontal areas is less likely for non-floating unicellular diazotrophs. The large cell type may be more prone to accumulation aided by the excretion of extracellular polymeric substances and formation of aggregates, a characteristic not described for the small cell type (Webb et al., 2009; Sohm et al., 2011) and implied previously to explain their distinct vertical distributions at the edge of an anticyclone (Bench et al., 2016). Wilson et al. (2017) quantified an $11 \%$ contribution to net community production attributed 
to $\mathrm{N}_{2}$ fixation by abundant Crocosphaera near an anticyclonic eddy, and an increased contribution of $\mathrm{N}_{2}$ fixation to particulate nitrogen export flux.

The uncultivated unicellular diazotroph UCYN-A is a small $(<1 \mu \mathrm{m})$ cyanobacterium in obligate symbiosis with a prymnesiophyte host to whom they provide fixed nitrogen in exchange for fixed carbon (Thompson et al., 2012). While widely distributed in warm low latitude seas (Moisander et al., 2010), UCYN-A also thrives in nutrient-rich and cold waters such as coastal upwelling ecosystems and polar seas (Agawin et al., 2014; Harding et al., 2018; Moreira-Coello et al., 2019). Both UCYN-A and its host are dependent on $\mathrm{N}_{2}$ fixation for their nitrogen needs even in the presence of abundant inorganic nitrogen, which has been found to stimulate $\mathrm{N}_{2}$ fixation (Mills et al., 2020). Such tolerance makes UCYN-A a good candidate to benefit from the biogeochemical conditions provided by eddy pumping in cyclonic eddies. However, abundant UCYN-A have been reported in anticyclones but not cyclones (Fong et al., 2008; Robidart et al., 2014; Liu et al., 2020). Perhaps driven by Ekman pumping of deep nutrientrich waters in anticyclonic eddies (Anderson et al., 2011), as proposed to explain higher abundances of Trichodesmium in cyclonic eddies in the North Atlantic (Olson et al., 2015). Counter to expectations, episodic nutrient advection at the periphery of an anticyclonic eddy has previously been found to contribute to lower nifH transcription from both UCYN-A and Crocosphaera (Robidart et al., 2019).

Non-cyanobacterial diazotrophs (bacteria and archaea) cannot photosynthesize, which renders them dependent on organic matter to fulfill their energy and carbon needs (Bombar et al., 2016) although other metabolisms such as chemolithoautotrophy are plausible (Riemann et al., 2010). Their prevalence in anticyclonic eddies has been attributed to the accumulation of organic matter within the core (Löscher et al., 2016), while a separate study finding higher abundances in cyclonic eddies predicted that is was due to the alleviation of phosphorus stress (Zhang et al., 2011). Finally, diatomdiazotroph associations (DDAs) dominate in low salinity and high silicate waters of river mouths such as the Mekong and the Amazon river plumes (Foster et al., 2007; Bombar et al., 2011). As the plume dilutes, the diazotrophic community shifts toward unicellular diazotroph ecotypes, indicating that the dispersion of the plume ultimately determines their geographical distribution (Grosse et al., 2010). In the oligotrophic North Pacific, Harke et al. (2019) measured coordinated gene expression between the Richelia-Rhizosolenia DDA over the same anticyclonic transect as Crocosphaera and Trichodesmium high-resolution metatranscriptomes mentioned previously (Wilson et al., 2017; Frischkorn et al., 2018, respectively). Comparative analysis of these metatranscriptomes within the dynamic physical environmental context may reveal conserved mechanisms of response associated with $\mathrm{N}_{2}$ fixation.

As discussed above, fine scale structures may affect diazotroph ecotypes in different ways according to their autoecology and physiology as well as trophic interactions within the planktonic community. The biogeochemical characteristics and trophic interactions taking place within these structures change between formation and dissipation. We thus predict that the impacts on diazotrophs evolve over the lifetime of these structures.

\section{TOOLS FOR HIGH-RESOLUTION DIAZOTROPH SAMPLING}

Fine scale structures are dynamic and ephemeral, making instrumentation for high-resolution measurements indispensable for their study. This instrumentation must be capable of providing activity, abundance and diversity data at spatiotemporal resolutions equal to or smaller than that of the physical and biological processes under study (Lévy et al., 2012). Below we present currently available technology to address the dynamics of diazotroph assemblages embedded in dynamic fine scale structures.

The studies that have sought to understand the role of fine scales on structuring diazotrophic communities or modulating $\mathrm{N}_{2}$ fixation rates have used traditional sampling approaches consisting of CTD-rosette casts at discrete stations. These approaches may suffice when applying a Lagrangian sampling strategy, i.e., following a given water mass at the pace it moves. However, ephemeral submesoscale structures associated with eddies are not easily quantified or characterized with traditional sampling (Johnson et al., 2010). In the past decade, technological developments have allowed the quantification of diazotroph ecotypes at a higher frequency than that provided by conventional sampling. The first study to do so used a towed video plankton recorder to continuously visualize Trichodesmium colonies across the North Atlantic, finding clear associations with anticyclones (Davis and McGillicuddy, 2006). Using an ecogenomic sensor, Robidart et al. (2014) found that diazotroph abundances changed over three orders of magnitude in less than 2 days and $30 \mathrm{~km}$ in the North Pacific. Most recently, a microbiological autosampler collected 1 sample/h over a transect in the North Atlantic, showing record abundances of UCYNA in cold coastal regions and less abundant Trichodesmium in warmer waters offshore (Tang et al., 2020). In the same region, another study with a spatial resolution of 1 sample each $\sim 5 \mathrm{~km}$ found peak abundances of Trichodesmium coinciding with steep gradients of current velocity at the edge of the Gulf Stream (Palter et al., 2020).

Geochemical approaches to measure $\mathrm{N}_{2}$ fixation include the $\mathrm{N}^{*}$ parameter, which measures the concentration of nitrate in excess (or deficit) of that expected from the remineralization of phosphate at Redfield stoichiometries (Gruber and Sarmiento, 1997). This method has been used to study diazotrophy within mesoscale eddies in the eastern tropical South Pacific (Löscher et al., 2016). The $\delta^{15} \mathrm{~N}$ approach measures the relative ${ }^{14} \mathrm{~N} /{ }^{15} \mathrm{~N}$ isotope signature and relates low values $\left(\delta^{15} \mathrm{~N} \sim 0.6 \% 0\right)$ to diazotrophic activity (Karl et al., 2002). Geochemical methods have the disadvantage that $\mathrm{N}_{2}$ fixation signatures $\left(\mathrm{N}^{*}>2.5 \mu \mathrm{mol}\right.$ $\mathrm{kg}^{-1}$ or low $\delta^{15} \mathrm{~N}$ values) can be caused by processes other than $\mathrm{N}_{2}$ fixation (Hastings et al., 2003; Zamora et al., 2010), but have the advantage that they can be used in large oceanic regions and are incubation-independent.

The most common biological method to measure $\mathrm{N}_{2}$ fixation rates is using stable isotope tracers in $24 \mathrm{~h}$ incubations 
(Montoya et al., 1996; White et al., 2020). In situ stable isotope incubations have been previously adapted to surface drifters (the Submersible Incubation Device, or SID), with $4 \times 24$ hour incubations per deployment (Bombar et al., 2015). Indirect methods such as hydrogen production measurements or the acetylene reduction assay allow working with smaller volumes and shorter incubation times, thus providing a faster measurement alternative for high spatiotemporal resolution studies. Hydrogen production measurements are based on the principle that $\mathrm{N}_{2}$ reduction produces hydrogen $\left(\mathrm{H}_{2}\right)$ in an equimolar reaction, so that every mole of $\mathrm{H}_{2}$ produced can be equated to a mole of $\mathrm{N}_{2}$ fixed (Wilson et al., 2010b). However, uptake hydrogenase enzymes are also present in diazotrophs to re-assimilate $\mathrm{H}_{2}$ and recover energy, altering the ratio of $\mathrm{N}_{2}$ reduced to $\mathrm{H}_{2}$ released, which in practice varies between 0.2 and 13 (Wilson et al., 2010b; Wilson et al., submitted). This method yields rates every $\sim 20 \mathrm{~min}$, and can be used in diel cycle studies (Wilson et al., 2010a,b) or on highfrequency measurements over oceanographic cruise transects (Moore et al., 2014, 2018).

The acetylene reduction assay is based on the ability of the nitrogenase enzyme to reduce other triple-bonded molecules such as acetylene, which is reduced to ethylene and converted to $\mathrm{N}_{2}$ fixation rates using a ratio of $3: 1$ or $4: 1$ depending on if hydrogen re-assimilation is considered or not (Stal, 1988; Capone, 1993), but just as with hydrogen measurements, empirically determined ratios vary widely (Mulholland et al., 2004, 2006). Recently, this assay has been adapted to measure continuous $\mathrm{N}_{2}$ fixation in underway seawater systems (Cassar et al., 2018; Tang et al., 2020). Indirect methods measure gross $\mathrm{N}_{2}$ fixation rates, i.e., how much $\mathrm{N}_{2}$ has been reduced by the nitrogenase enzyme, independent of whether it is channeled to diazotroph biomass or released extracellularly as dissolved nitrogen compounds. Because diazotrophs are known to release significant amounts of fixed $\mathrm{N}_{2}$ extracellularly (Mulholland et al., 2004; Benavides et al., 2013; Berthelot et al., 2015; Bonnet et al., 2016), gross $\mathrm{N}_{2}$ fixation measurements may provide better estimates of fixed $\mathrm{N}_{2}$ inputs to the ocean.

\section{FUTURE PERSPECTIVES}

In situ DNA sensors, samplers and rate measurements have provided abundance or activity data at an unprecedented spatiotemporal resolution. Understanding how fine scales shape diazotroph communities requires the combination of diazotroph identification, enumeration and $\mathrm{N}_{2}$ fixation measurements at high, 4-dimensional spatiotemporal resolution.

Directed sampling within fine scale structures can be challenging, requiring the inspection of hydrographic variables and Lagrangian structures prior to the cruise (Nencioli et al., 2011; Doglioli et al., 2013). Following Lagrangian coherent structures requires the deployment of floats or vehicles capable of geolocalizing a moving water parcel. Fronts and mesoscale eddies are easier to characterize than ephemeral structures such as submesoscale filaments. Importantly, synoptic measurements of physical and chemical variables including horizontal and vertical current speed, vorticity, vertical turbulent microstructure and inorganic and organic nutrient diffusion are needed to comprehensively understand how fine scale processes affect diazotrophs.

Recent advances in vehicles and sensors will contribute to our understanding of physical-chemical-biological interactions in situ. Measurements of turbulence are becoming more frequent on seagliders (e.g., Fernández-Castro et al., 2020). Deployed nutrient sensors with nanomolar limits of detection (Beaton et al., 2012) can facilitate the observation of episodic or small-scale events in oligotrophic mixed layers. Autonomous vehicles capable of Lagrangian drift can follow specific water masses, sampling the microbial community in its environmental context (Birch et al., 2019) and autonomous orientation using chlorophyll concentrations allows targeted sampling of structures within the water column (Zhang et al., 2019). Deployments of combined sensors will enable a more thorough understanding of diazotroph - environmental interactions on fine scales, to be integrated across water masses for larger scale understanding. Measurements of flux, although currently providing data at higher resolution (Bombar et al., 2015; Tang et al., 2019; Wilson et al., submitted) currently require ship-based manipulations and/or analysis and are not yet capable of in situ deployment. Integrated, cross-disciplinary field-based efforts are crucial to resolve effects of short spatiotemporal scale dynamic processes fundamental to microbial activity.

\section{RECOMMENDATIONS}

Providing detailed sampling procedures to study the effects of fine scale structures on diazotrophs is challenging since dedicated high-resolution sampling devices are not widely available nor standardized for the oceanographic community. Nevertheless, dedicated study of fine scale processes is required in order to connect biological processes to underpinning physical and biogeochemical drivers. Below we provide a list of recommendations hoping to inspire microbial oceanographers to embrace such studies in their research programs.

(1) Fine scales are dynamic and ephemeral, requiring Lagrangian sampling approaches. Prior geolocalization of structures with satellite products is required for targeted sampling. Post-cruise satellite-derived data such as altimetry and ocean color aid description of underlying physical processes. In addition, in situ measurements of current speed and vertical mixing are highly recommended to better constrain fine scale structures.

(2) High-resolution measurements within large eddies can deliver the same diazotroph dynamics observed via longterm Eulerian measurements in time-series station data (McGillicuddy et al., 1999; Robidart et al., 2014). Since comprehensive time-series stations cannot be implemented across the global oceans, strategic observations targeting fine scale features should be implemented in representative oceanic provinces to capture biogeochemical variability over short field programs. 
(3) Diazotroph abundance and diversity measurements should be measured synoptically with $\mathrm{N}_{2}$ fixation measurements. Fine scales comprise a wide array of structures which may affect different diazotroph phylotypes in disparate ways. Coupling activity and abundance/diversity measurements will provide insights into passive (accumulation) versus active ( $\mathrm{N}_{2}$ fixation activity stimulation) effects on diazotrophs.

(4) Growth and mortality measurements should be implemented (e.g., Dugenne et al., 2020). While few studies have attempted to measure in situ growth of diazotroph phylotypes, redistribution of assemblages by fine scale structures may alter the balance between growth, mortality and predator pressure.

\section{DATA AVAILABILITY STATEMENT}

All datasets presented in this study are included in the article/supplementary material.

\section{REFERENCES}

Agawin, N. S. R., Benavides, M., Busquets, A., Ferriol, P., Stal, L. J., and Arístegui, J. (2014). Dominance of unicellular cyanobacteria in the diazotrophic community in the Atlantic Ocean. Limnol. Oceanogr. 59, 623-637. doi: 10.4319/lo.2014.59. 2.0623

Anderson, L. A., McGillicuddy, D. J., Maltrud, M. E., Lima, I. D., and Doney, S. C. (2011). Impact of eddy-wind interaction on eddy demographics and phytoplankton community structure in a model of the North Atlantic Ocean. Dyn. Atmos. Ocean. 52, 80-94. doi: 10.1016/j.dynatmoce.2011.01.003

Bates, N. R., and Hansell, D. A. (2004). Temporal variability of excess nitrate in the subtropical mode water of the North Atlantic Ocean. Mar. Chem. 84, 225-241. doi: 10.1016/j.marchem.2003.08.003

Beaton, A. D., Cardwell, C. L., Thomas, R. S., Sieben, V. J., Legiret, F. E., Waugh, E. M., et al. (2012). Lab-on-chip measurement of nitrate and nitrite for in situ analysis of natural waters. Environ. Sci. Technol. 46, 9548-9556. doi: 10.1021/ es300419u

Benavides, M., Bronk, D. A., Agawin, N. S. R., Pérez-Hernández, M. D., Hernández-Guerra, A., and Arístegui, J. (2013). Longitudinal variability of sizefractionated N2 fixation and DON release rates along $24.5^{\circ} \mathrm{N}$ in the subtropical North Atlantic. J. Geophys. Res. Ocean 118, 3406-3415. doi: 10.1002/jgrc. 20253

Benavides, M., Moisander, P., Daley, M. C., Bode, A., and Arístegui, J. (2016). Longitudinal variability of diazotroph abundances in the subtropical North Atlantic Ocean. J. Plankton Res. 38, 662-672. doi: 10.1093/plankt/fbv121

Bench, S. R., Frank, I., Robidart, J., and Zehr, J. P. (2016). Two subpopulations of Crocosphaera watsonii have distinct distributions in the North and South Pacific. Environ. Microbiol. 18, 514-524. doi: 10.1111/1462-2920.13180

Berman-Frank, I., Bidle, K. D., Haramaty, L., and Falkowski, P. G. (2004). The demise of the marine cyanobacterium, Trichodesmium spp., via an autocatalyzed cell death pathway. Limnol. Oceanogr. 49, 997-1005. doi: 10.4319/ lo.2004.49.4.0997

Berthelot, H., Bonnet, S., Camps, M., Grosso, O., and Moutin, T. (2015). Assessment of the dinitrogen released as ammonium and dissolved organic nitrogen by unicellular and filamentous marine diazotrophic cyanobacteria grown in culture. Front. Mar. Sci. 2:80. doi: 10.3389/fmars.2015.00080

Birch, J., Barone, B., Delong, E., Foreman, G., Gomes, K., Hobson, B., et al. (2019). "Autonomous targeted sampling of the deep chlorophyll maximum layer in a subtropical North Pacific eddy," in Proceedings of the Oceans 2018 MTS/IEEE Charleston, Charleston, SC, 1-5. doi: 10.1109/OCEANS.2018.8604898

Bombar, D., Moisander, P. H., Dippner, J. W., Foster, R. A., Voss, M., Karfeld, B., et al. (2011). Distribution of diazotrophic microorganisms and nifH gene

\section{AUTHOR CONTRIBUTIONS}

All authors listed have made a substantial, direct and intellectual contribution to the work, and approved it for publication.

\section{FUNDING}

This work was funded by the project DEFINE (INSU-LEFECYBER), granted to MB. JR was supported by NERC grants NE/N006496/1 and NE/R015953/1.

\section{ACKNOWLEDGMENTS}

We would like to thank Samuel T. Wilson, Nicolas Cassar, and Weiyi Tang for their pioneering and inspiring work on highresolution $\mathrm{N}_{2}$ fixation sampling.

expression in the Mekong River plume during intermonsoon. Mar. Ecol. Prog Ser. 424, 39-52. doi: 10.3354/meps08976

Bombar, D., Paerl, R. W., and Riemann, L. (2016). Marine non-cyanobacterial diazotrophs: moving beyond molecular detection. Trends Microbiol. 24, 916927. doi: 10.1016/j.tim.2016.07.002

Bombar, D., Taylor, C. D., Wilson, S. T., Robidart, J. C., Rabines, A., Turk-Kubo, K. A., et al. (2015). Measurements of nitrogen fixation in the oligotrophic North Pacific Subtropical Gyre using a free-drifting submersible incubation device. $J$. Plankton Res. 37, 727-739. doi: 10.1093/plankt/fbv049

Bombar, D., Turk-Kubo, K. A., Robidart, J., Carter, B. J., and Zehr, J. P. (2013). Non-cyanobacterial nifH phylotypes in the North Pacific Subtropical Gyre detected by flow-cytometry cell sorting. Environ. Microbiol. Rep. 5, 705-715. doi: 10.1111/1758-2229.12070

Bonnet, S., Berthelot, H., Turk-Kubo, K., Cornet-Barthaux, V., Fawcett, S., Berman-Frank, I., et al. (2016). Diazotroph derived nitrogen supports diatom growth in the South West Pacific: a quantitative study using nanoSIMS. Limnol. Oceanogr. 61, 1549-1562. doi: 10.1002/lno.10300

Bonnet, S., Rodier, M., Turk-Kubo, K. A., Germineaud, C., Menkes, C., Ganachaud, A., et al. (2015). Contrasted geographical distribution of N2 fixation rates and nifH phylotypes in the Coral and Solomon Seas (southwestern Pacific) during austral winter conditions. Glob. Biogeochem. Cycles 29, 1874-1892. doi: 10.1002/ 2015GB005117

Bracco, A., Provenzale, A., and Scheuring, I. (2000). Mesoscale vortices and the paradox of the plankton. Proc. R. Soc. B Biol. Sci. 267, 1795-1800. doi: 10.1098/ rspb.2000.1212

Caffin, M., Moutin, T., Ann Foster, R., Bouruet-Aubertot, P., Michelangelo Doglioli, A., Berthelot, H., et al. (2018). N2 fixation as a dominant new N source in the western tropical South Pacific Ocean (OUTPACE cruise). Biogeosciences 15, 2565-2585. doi: 10.5194/bg-15-2565-2018

Capone, D. G. (1993). "Determination of nitrogenase activity in aquatic samples using the acetylene reduction procedure," in Handbook of Methods in Aquatic Microbial Ecology, eds P. F. Kemp, J. J. Cole, B. F. Sherr, and E. B. Sherr (Boca Raton, FL: CRC Press), 621-631. doi: 10.1201/9780203752 746-74

Cassar, N., Tang, W., Gabathuler, H., and Huang, K. (2018). A method for high frequency underway N2 fixation measurements: flow-through incubation acetylene reduction assays by cavity ring down laser absorption spectroscopy (FARACAS). Anal. Chem. 90, 2839-2851. doi: 10.1021/acs.analchem.7b0 4977

Davis, C. S., and McGillicuddy, D. J. (2006). Transatlantic abundance of the N2fixing colonial cyanobacterium Trichodesmium. Science 312, 1517-1520. doi: $10.1126 /$ science. 1123570 
Deutsch, C., Sarmiento, J. L., Sigman, D. M., Gruber, N., and Dunne, J. P. (2007). Spatial coupling of nitrogen inputs and losses in the ocean. Nature 445, 163-167. doi: $10.1038 /$ nature 05392

Doglioli, A. M., Nencioli, F., Petrenko, A. A., Rougier, G., Fuda, J. L., and Grima, N. (2013). A Software package and hardware tools for in situ experiments in a Lagrangian reference frame. J. Atmos. Ocean. Technol. 30, 1940-1950. doi: 10.1175/JTECH-D-12-00183.1

d'Ovidio, F., De Monte, S., Alvain, S., Dandonneau, Y., and Levy, M. (2010). Fluid dynamical niches of phytoplankton types. Proc. Natl. Acad. Sci. U.S.A. 107, 18366-18370. doi: 10.1073/pnas.1004620107

Dugenne, M., Freitas, F. H., Wilson, S. T., Karl, D. M., and White, A. E. (2020). Life and death of Crocosphaera sp. in the Pacific Ocean: fine scale predator - prey dynamics. Limnol. Ocean doi: 10.1002/lno.11473

Dutkiewicz, S., Ward, B. A., Scott, J. R., and Follows, M. J. (2014). Understanding predicted shifts in diazotroph biogeography using resource competition theory. Biogeosciences 11, 5445-5461. doi: 10.5194/bg-11-5445-2014

Dyhrman, S. T., Chappell, P. D., Haley, S. T., Moffett, J. W., Orchard, E. D., Waterbury, J. B., et al. (2006). Phosphonate utilization by the globally important marine diazotroph Trichodesmium. Nature 439, 68-71. doi: 10.1111/1758-2229. 12308

Eichner, M., Basu, S., Wang, S., de Beer, D., and Shaked, Y. (2019). Mineral iron dissolution in Trichodesmium colonies: the role of $\mathrm{O} 2$ and $\mathrm{pH}$ microenvironments. Limnol. Oceanogr. 65, 1149-1160. doi: 10.1002/lno. 11377

Eichner, M. J., Klawonn, I., Wilson, S. T., Littmann, S., Whitehouse, M. J., Church, M. J., et al. (2017). Chemical microenvironments and single-cell carbon and nitrogen uptake in field-collected colonies of Trichodesmium under different pCO2. ISME J. 11, 1305-1317. doi: 10.1038/ismej.2017.15

Falkowski, P. G., Ziemann, D., Kolber, Z., and Bienfang, P. K. (1991). Role of eddy pumping in enhancing primary production in the ocean. Nature 349, 373-374.

Fernández-Castro, B., Evans, D. G., Frajka-Williams, E., Vic, C., and NaveiraGarabato, A. C. (2020). Breaking of internal waves and turbulent dissipation in an anticyclonic mode water eddy. J. Phys. Oceanogr. 50, 1893-1914. doi: 10.1175/jpo-d-19-0168.1

Finzi-Hart, J. A., Pett-Ridge, J., Weber, P. K., Popa, R., Fallon, S. J., Gunderson, T., et al. (2009). Fixation and fate of $\mathrm{C}$ and $\mathrm{N}$ in the cyanobacterium Trichodesmium using nanometer-scale secondary ion mass spectrometry. Proc. Natl. Acad. Sci. U.S.A. 106, 6345-6350. doi: 10.1073/pnas.0810547106

Fong, A. A., Karl, D. M., Lukas, R., Letelier, R. M., Zehr, J. P., and Church, M. J. (2008). Nitrogen fixation in an anticyclonic eddy in the oligotrophic North Pacific Ocean. ISME J. 2, 663-676. doi: 10.1038/ismej.2008.22

Foster, R. A., Carpenter, E. J., and Bergman, B. (2006). Unicellular cyanobionts in open ocean dinoflagellates, radiolarians, and tintinnids: ultrastructural characterization and immuno-localization of phycoerythrin and nitrogenase. J. Phycol. 42, 453-463. doi: 10.1111/j.1529-8817.2006.00206.x

Foster, R. A., Subramaniam, A., Mahaffey, C., Carpenter, E. J., Capone, D. G., and Zehr, J. P. (2007). Influence of the Amazon River plume on distributions of free-living and symbiotic cyanobacteria in the western tropical north Atlantic Ocean. Limnol. Oceanogr. 52, 517-532. doi: 10.4319/lo.2007.52.2. 0517

Frischkorn, K. R., Haley, S. T., and Dyhrman, S. T. (2018). Coordinated gene expression between Trichodesmium and its microbiome over day-night cycles in the North Pacific Subtropical Gyre. ISME J. 12, 997-1007. doi: 10.1038/s41396017-0041-5

Grosse, J., Bombar, D., Doan, H. N., Nguyen, L. N., and Voss, M. (2010). The Mekong River plume fuels nitrogen fixation and determines phytoplankton species distribution in the South China Sea during low- and high-discharge season. Limnol. Oceanogr. 55, 1668-1680. doi: 10.4319/lo.2010.55.4.1668

Gruber, N. (2016). Elusive marine nitrogen fixation. Proc. Natl. Acad. Sci. U.S.A. 113, 4246-4248. doi: 10.1073/pnas.1603646113

Gruber, N., and Sarmiento, J. L. (1997). Global patterns of marine nitrogen fixation and denitrification. Glob. Biogeochem. Cycles 11, 235-266. doi: 10.1029/ $97 \mathrm{gb} 00077$

Guidi, L., Calil, P. H. R., Duhamel, S., Björkman, K. M., Doney, S. C., Jackson, G. A., et al. (2012). Does eddy-eddy interaction control surface phytoplankton distribution and carbon export in the North Pacific Subtropical Gyre? J. Geophys. Res. Biogeosci. 117:G02024. doi: 10.1029/2012JG001984
Hansell, D. A., Bates, N. R., and Olson, D. B. (2004). Excess nitrate and nitrogen fixation in the North Atlantic Ocean. Mar. Chem. 84, 243-265. doi: 10.1016/j. marchem.2003.08.004

Harding, K., Turk-Kubo, K. A., Sipler, R. E., Mills, M. M., Bronk, D. A., and Zehr, J. P. (2018). Symbiotic unicellular cyanobacteria fix nitrogen in the Arctic Ocean. Proc. Natl. Acad. Sci. U.S.A. 115, 13371-13375. doi: 10.1073/pnas. 1813658115

Harke, M. J., Frischkorn, K. R., Haley, S. T., Aylward, F. O., Zehr, J. P., and Dyhrman, S. T. (2019). Periodic and coordinated gene expression between a diazotroph and its diatom host. ISME J. 13, 118-131. doi: 10.1038/s41396-0180262-2

Hastings, M. G., Sigman, D. M., and Lipschultz, F. (2003). Isotopic evidence for source changes of nitrate in rain at Bermuda. J. Geophys. Res. 108:4790. doi: 10.1029/2003jd003789

Hood, R. R., Subramaniam, A., May, L. R., Carpenter, E. J., and Capone, D. G. (2002). Remote estimation of nitrogen fixation by Trichodesmium. Deep Sea Res. II Top. Stud. Oceanogr. 49, 123-147.

Hynes, A. M., Chappell, P. D., Dyhrman, S. T., Doney, S. C., and Webb, E. A. (2009). Cross-basin comparison of phosphorus stress and nitrogen fixation in Trichodesmium. Limnol. Oceanogr. 54, 1438-1448. doi: 10.4319/lo.2009.54.5. 1438

Johnson, K. S., Riser, S. C., and Karl, D. M. (2010). Nitrate supply from deep to near-surface waters of the North Pacific subtropical gyre. Nature 465, 1062 1065. doi: 10.1038/nature09170

Karl, D., Michaels, A., Bergman, B., Capone, D., Carpenter, E., Letelier, R., et al. (2002). Dinitrogen fixation in the world's oceans. Biogeochemistry 57/58, 47-98. doi: 10.1007/978-94-017-3405-9_2

Karl, D. M., Church, M. J., Dore, J. E., Letelier, R. M., and Mahaffey, C. (2012). Predictable and efficient carbon sequestration in the North Pacific Ocean supported by symbiotic nitrogen fixation. Proc. Natl. Acad. Sci. U.S.A. 109, 1842-1849. doi: 10.1073/pnas.1120312109

Knapp, A. N., Casciotti, K. L., Berelson, W. M., Prokopenko, M. G., and Capone, D. G. (2016). Low rates of nitrogen fixation in eastern tropical South Pacific surface waters. Proc. Natl. Acad. Sci. U.S.A. 113, 4398-4403. doi: 10.1073/pnas. 1515641113

Knapp, A. N., Dekaezemacker, J., Bonnet, S., Sohm, J. A., and Capone, D. G. (2012). Sensitivity of Trichodesmium erythraeum and Crocosphaera watsonii abundance and N-2 fixation rates to varying NO3-and PO43-concentrations in batch cultures. Aquat. Microb. Ecol. 66, 223-236. doi: 10.3354/ame 01577

Landolfi, A., Kähler, P., Koeve, W., and Oschlies, A. (2018). Global marine N2 fixation estimates: from observations to models. Front. Microbiol. 9:2112. doi: 10.3389/fmicb.2018.02112

Landolfi, A., Oschlies, A., and Sanders, R. (2008). Organic nutrients and excess nitrogen in the North Atlantic subtropical gyre. Biogeosciences 5, 1199-1213. doi: 10.5194/bg-5-1199-2008

Lehahn, Y., D’Ovidio, F., and Koren, I. (2017a). A satellite-based lagrangian view on phytoplankton dynamics. Ann. Rev. Mar. Sci. 10, 99-119. doi: 10.1146/ annurev-marine-121916-063204

Lehahn, Y., Koren, I., Sharoni, S., D’Ovidio, F., Vardi, A., and Boss, E. (2017b). Dispersion/dilution enhances phytoplankton blooms in low-nutrient waters. Nat. Commun. 8:14868. doi: 10.1038/ncomms 14868

Lehahn, Y., D’Ovidio, F., Lévy, M., Amitai, Y., and Heifetz, E. (2011). Long range transport of a quasi isolated chlorophyll patch by an Agulhas ring. Geophys. Res. Lett. 38:L16610. doi: 10.1029/2011GL048588

Lehahn, Y., Koren, I., Schatz, D., Frada, M., Sheyn, U., Boss, E., et al. (2014). Decoupling physical from biological processes to assess the impact of viruses on a mesoscale algal bloom. Curr. Biol. 24, 2041-2046. doi: 10.1016/j.cub.2014. 07.046

Lévy, M., Ferrari, R., Franks, P. J. S., Martin, A. P., and Rivière, P. (2012). Bringing physics to life at the submesoscale. Geophys. Res. Lett. 39:L14602. doi: 10.1029/ 2012GL052756

Lin, S., Henze, S., Lundgren, P., Bergman, B., and Carpenter, E. J. (1998). Wholecell immunolocalization of nitrogenase in marine diazotrophic cyanobacteria, Trichodesmium spp. Appl. Environ. Microbiol. 64, 3052-3058. doi: 10.1128/ aem.64.8.3052-3058.1998

Liu, J., Zhou, L., Li, J., Lin, Y., Ke, Z., Zhao, C., et al. (2020). Effect of mesoscale eddies on diazotroph community structure and nitrogen fixation rates in the 
South China Sea. Reg. Stud. Mar. Sci. 35:101106. doi: 10.1016/j.rsma.2020. 101106

Löscher, C. R., Bourbonnais, A., Dekaezemacker, J., Charoenpong, C. N., Altabet, M. A., Bange, H. W., et al. (2016). N2 fixation in eddies of the eastern tropical South Pacific Ocean. Biogeosciences 13, 2889-2899.

Luo, Y.-W., Doney, S. C., Anderson, L. A., Benavides, M., Berman-Frank, I., Bode, A., et al. (2012). Database of diazotrophs in global ocean: abundance, biomass and nitrogen fixation rates. Earth Syst. Sci. Data 4, 47-73.

Mahadevan, A. (2016). The impact of submesoscale physics on primary productivity of plankton. Ann. Rev. Mar. Sci. 8, 161-184. doi: 10.1146/annurevmarine-010814-015912

Mahaffey, C., Michaels, A. F., and Capone, D. G. (2005). The conundrum of marine N2 fixation. Am. J. Sci. 305, 546-595. doi: 10.2475/ajs.305.6-8.546

McGillicuddy, D. J. (2016). Mechanisms of physical-biological-biogeochemical interaction at the oceanic mesoscale. Ann. Rev. Mar. Sci. 8, 125-159. doi: 10.1146/annurev-marine-010814-015606

McGillicuddy, D. J., Johnson, R., Siegel, D. A., Michaels, A. F., Bates, N. R., and Knap, A. H. (1999). Mesoscale variations of biogeochemical properties in the Sargasso Sea. J. Geophys. Res. Ocean. 104, 13381-13394. doi: 10.1029/ 1999jc900021

McInnes, A. S., Shepard, A. K., Raes, E. J., Waite, A. M., and Quigg, A. (2014). Simultaneous quantification of active carbon- and nitrogen-fixing communities and estimation of fixation rates using fluorescence in situ hybridization and flow cytometry. Appl. Environ. Microbiol. 80, 6750-6759. doi: 10.1128/aem.019 62-14

Mills, M. M., and Arrigo, K. R. (2010). Magnitude of oceanic nitrogen fixation influenced by the nutrient uptake ratio of phytoplankton. Nat. Geosci. 3, 412-416. doi: 10.1038/ngeo856

Mills, M. M., Turk-Kubo, K. A., van Dijken, G. L., Henke, B. A., Harding, K., Wilson, S. T., et al. (2020). Unusual marine cyanobacteria/haptophyte symbiosis relies on $\mathrm{N} 2$ fixation even in $\mathrm{N}$-rich environments. ISME J. [Epub ahead of print].

Moisander, P. H., Beinart, R. A., Hewson, I., White, A. E., Johnson, K. S., Carlson, C. A., et al. (2010). Unicellular cyanobacterial distributions broaden the oceanic N2 fixation domain. Science 327, 1512-1514. doi: 10.1126/science.118 5468

Monteiro, F. M., Dutkiewicz, S., and Follows, M. J. (2011). Biogeographical controls on the marine nitrogen fixers. Glob. Biogeochem. Cycles 25:GB2003. doi: 10. 1029/2010GB003902

Montoya, J. P., Voss, M., Kahler, P., and Capone, D. G. (1996). A simple, highprecision, high-sensitivity tracer assay for N2 fixation. Appl. Environ. Microbiol. 62, 986-993. doi: 10.1128/aem.62.3.986-993.1996

Moore, R. M., Grefe, I., Zorz, J., Shan, S., Thompson, K., Ratten, J., et al. (2018). On the relationship between hydrogen saturation in the tropical Atlantic Ocean and nitrogen fixation by the symbiotic diazotroph UCYN-A. J. Geophys. Res. Ocean. 123, 2353-2362. doi: 10.1002/2017JC013047

Moore, R. M., Kiensat, M., Fraser, M., Cullen, J. J., Deutsch, C., Dutkiewicz, S., et al. (2014). Extensive hydrogen supersaturations in the western South Atlantic Ocean suggest substantial underestimation of nitrogen fixation. J. Geophys. Res. Ocean. 119, 4340-4350. doi: 10.1002/2014jc010017

Moreira-Coello, V., Mouriño-Carballido, B., Marañón, E., Fernández, A., Bode, A., Sintes, E., et al. (2019). Temporal variability of diazotroph community composition in the upwelling region off NW Iberia. Sci. Rep. 9:3737.

Mulholland, M. R., Bernhardt, P. W., Heil, C. A., Bronk, D. A., and Neil, J. M. O. (2006). Nitrogen fixation and release of fixed nitrogen by Trichodesmium spp. in the Gulf of Mexico. Limnol. Oceanogr. 51, 1762-1776. doi: 10.4319/lo.2006. 51.4.1762

Mulholland, M. R., Bronk, D. A., and Capone, D. G. (2004). Dinitrogen fixation and release of ammonium and dissolved organic nitrogen by Trichodesmium IMS101. Aquat. Microb. Ecol. 37, 85-94. doi: 10.3354/ame037085

Nencioli, F., D'Ovidio, F., Doglioli, A. M., and Petrenko, A. A. (2011). Surface coastal circulation patterns by in-situ detection of Lagrangian coherent structures. Geophys. Res. Lett. 38:L17604. doi: 10.1029/2011GL0 48815

Olson, E., McGillicuddy, D. J., Flierl, G. R., Davis, C. S., Dyhrman, S. T., and Waterbury, J. (2015). Mesoscale eddies and Trichodesmium spp. distributions in the southwestern North Atlantic. J. Geophys. Res. Ocean. 120, 4129-4150. doi: $10.1002 / 2015 j \mathrm{j} 010728$
Palter, J. B., Ames, E., Benavides, M., Gonçalves, A., Granger, J., Moisander, P. H., et al. (2020). High N2 fixation in and near the Gulf Stream consistent with a circulation control on diazotrophy. Geophys. Res. Lett. 47:e2020GL089103.

Riemann, L., Farnelid, H., and Steward, G. F. (2010). Nitrogenase genes in noncyanobacterial plankton: prevalence, diversity and regulation in marine waters. Aquat. Microb. Ecol. 61, 235-247. doi: 10.3354/ame01431

Robidart, J. C., Church, M. J., Ryan, J. P., Ascani, F., Wilson, S. T., Bombar, D., et al. (2014). Ecogenomic sensor reveals controls on N2-fixing microorganisms in the North Pacific Ocean. ISME J. 8, 1175-1185. doi: 10.1038/ismej.2013.244

Robidart, J. C., Magasin, J. D., Shilova, I. N., Turk-Kubo, K. A., Wilson, S. T., Karl, D. M., et al. (2019). Effects of nutrient enrichment on surface microbial community gene expression in the oligotrophic North Pacific Subtropical Gyre. ISME J. 13, 374-387. doi: 10.1038/s41396-018-0280-0

Rousset, G., De Boissieu, F., Menkes, C. E., Lefèvre, J., Frouin, R., Rodier, M., et al. (2018). Remote sensing of Trichodesmium spp. mats in the western tropical South Pacific. Biogeosciences 15, 5203-5219. doi: 10.5194/bg-15-5203-2018

Shiozaki, T., Bombar, D., Riemann, L., Hashihama, F., Takeda, S., Yamaguchi, T., et al. (2017). Basin scale variability of active diazotrophs and nitrogen fixation in the North Pacific, from the tropics to the subarctic Bering Sea. Glob. Biogeochem. Cycles 31, 996-1009. doi: 10.1002/2017GB005681

Sohm, J. A., Edwards, B. R., Wilson, B. G., and Webb, E. A. (2011). Constitutive extracellular polysaccharide (EPS) production by specific isolates of Crocosphaera watsonii. Front. Microbiol. 2:229. doi: 10.3389/fmicb.2011. 00229

Stal, L. J. (1988). Nitrogen fixation in cyanobacterial mats. Methods Enzymol. 167, 474-490. doi: 10.1016/0076-6879(88)67052-2

Subramaniam, A., Brown, C. W., Hood, R. R., Carpenter, E. J., and Capone, D. G. (2002). Detecting Trichodesmium blooms in Sea WiFS imagery. Deep Sea Res. II Top. Stud. Oceanogr. 49, 107-121. doi: 10.1016/s0967-0645(01)00 096-0

Tang, W., Cerdán, E., Berthelot, H., Polyviou, D., Wang, S., Baylay, H., et al. (2020). New insights into the distributions of nitrogen fixation and diazotrophs revealed by high-resolution sensing and sampling methods. ISME J. 14, 25142526.

Tang, W., Wang, S., Fonseca-Batista, D., Dehairs, F., Gifford, S., Gonzalez, A. G., et al. (2019). Revisiting the distribution of oceanic N2 fixation and estimating diazotrophic contribution to marine production. Nat. Commun. 10:831.

Taylor, J. R. (2018). Accumulation and subduction of buoyant material at submesoscale fronts. J. Phys. Oceanogr. 48, 1233-1241. doi: 10.1175/JPO-D-170269.1

Thompson, A. W., Foster, R. A., Krupke, A., Carter, B. J., Musat, N., Vaulot, D., et al. (2012). Unicellular cyanobacterium symbiotic with a single-celled eukaryotic alga. Science 337, 1546-1550. doi: 10.1126/science. 1222700

Thompson, A. W., and Zehr, J. P. (2013). Cellular interactions: lessons from the nitrogen-fixing cyanobacteria. J. Phycol. 49, 1024-1035. doi: 10.1111/jpy.12117

Torres-Valdés, S., Roussenov, V. M., Sanders, R., Reynolds, S., Pan, X., Mather, R., et al. (2009). Distribution of dissolved organic nutrients and their effect on export production over the Atlantic Ocean. Glob. Biogeochem. Cycles 23:GB4019. doi: 10.1029/2008GB003389

Tyrrell, T. (1999). The relative in inluences of nitrogen and phosphorus on oceanic primary production. Nature 400, 525-530. doi: 10.1038/22941

Villareal, T. A., and Carpenter, E. J. (2003). Buoyancy regulation and the potential for vertical migration in the oceanic cyanobacterium Trichodesmium. Microb. Ecol. 45, 1-10. doi: 10.1007/s00248-002-1012-5

Wang, W. L., Moore, J. K., Martiny, A. C., and Primeau, F. W. (2019). Convergent estimates of marine nitrogen fixation. Nature 566, 205-211. doi: 10.1038/ s41586-019-0911-2

Ward, B. A., Dutkiewicz, S., Moore, C. M., and Follows, M. J. (2013). Iron, phosphorus, and nitrogen supply ratios define the biogeography of nitrogen fixation. Limnol. Oceanogr. 58, 2059-2075. doi: 10.4319/lo.2013.58.6.2059

Webb, E. A., Ehrenreich, I. M., Brown, S. L., Valois, F. W., and Waterbury, J. B. (2009). Phenotypic and genotypic characterization of multiple strains of the diazotrophic cyanobacterium, Crocosphaera watsonii, isolated from the open ocean. Environ. Microbiol. 11, 338-348. doi: 10.1111/j.1462-2920.2008.01771.x

White, A. E., Granger, J., Selden, C., Gradoville, M. R., Potts, L., Bourbonnais, A., et al. (2020). A critical review of the $15 \mathrm{~N} 2$ tracer method to measure diazotrophic production in pelagic ecosystems. Limnol. Oceanogr. Methods 18, 129-147. doi: 10.1002/lom 3.10353 
White, A. E., Watkins-Brandt, K. S., and Church, M. J. (2018). Temporal variability of Trichodesmium spp. and diatom-diazotroph assemblages in the North Pacific Subtropical Gyre. Front. Mar. Sci 5:27. doi: 10.3389/fmars.2018. 00027

Wilson, S. T., Aylward, F. O., Ribalet, F., Barone, B., Casey, J. R., Connell, P. E., et al. (2017). Coordinated regulation of growth, activity and transcription in natural populations of the unicellular nitrogen-fixing cyanobacterium Crocosphaera. Nat. Microbiol. 2:17118. doi: 10.1038/nmicrobiol.2017.118

Wilson, S. T., Foster, R. A., Zehr, J. P., and Karl, D. M. (2010a). Hydrogen production by Trichodesmium erythraeum Cyanothece sp. and Crocosphaera watsonii. Aquat. Microb. Ecol. 59, 197-206. doi: 10.3354/ame01407

Wilson, S. T., Tozzi, S., Foster, R. A., Ilikchyan, I., Kolber, Z. S., Zehr, J. P., et al. (2010b). Hydrogen cycling by the unicellular marine diazotroph Crocosphaera watsonii strain WH8501. Appl. Environ. Microbiol. 76, 6797-6803.

Zamora, L. M., Landolfi, A., Oschlies, A., Hansell, D. A., Dietze, H., and Dentener, F. (2010). Atmospheric deposition of nutrients and excess $\mathrm{N}$ formation in the North Atlantic. Biogeosciences 7, 777-793.

Zehr, J. P., and Capone, D. G. (2020). Changing perspectives in marine nitrogen fixation. Science 368:eaay9514. doi: 10.1126/science.aay9514

Zhang, Y., Kieft, B., Hobson, B. W., Ryan, J. P., Barone, B., Preston, C. M., et al. (2019). Autonomous tracking and sampling of the deep chlorophyll maximum layer in an open-ocean eddy by a long-range autonomous underwater vehicle. IEEE J. Ocean. Eng. 99, 1-14. doi: 10.1109/joe.2019.292 0217

Zhang, Y., Zhao, Z., Sun, J., and Jiao, N. (2011). Diversity and distribution of diazotrophic communities in the South China Sea deep basin with mesoscale cyclonic eddy perturbations. FEMS Microbiol. Ecol. 78, 417-427. doi: 10.1111/j. 1574-6941.2011.01174.x

Zobell, C. E., and Anderson, D. Q. (1936). Observations on the multiplication of bacteria in different volumes of stored sea water and the influence of oxygen tension and solid surfaces. Biol. Bull. 71, 324-342.

Conflict of Interest: The authors declare that the research was conducted in the absence of any commercial or financial relationships that could be construed as a potential conflict of interest.

Copyright $\odot 2020$ Benavides and Robidart. This is an open-access article distributed under the terms of the Creative Commons Attribution License (CC BY). The use, distribution or reproduction in other forums is permitted, provided the original author(s) and the copyright owner(s) are credited and that the original publication in this journal is cited, in accordance with accepted academic practice. No use, distribution or reproduction is permitted which does not comply with these terms. 